音声言語医学 $56 ： 192-198,2015$

症例

\title{
高齢で発症した心因性吃音症例の経過
}

\author{
谷合 信一1) 前新 直志 ${ }^{2)}$ 田中 伸明 ${ }^{1)}$ 栗岡 隆臣 ${ }^{1)}$ \\ 冨藤 雅之 ${ }^{1)}$ 荒木 幸仁 ${ }^{1)}$ 塩谷 彰浩1)
}

\begin{abstract}
要 約：高齢で突発した心因性吃音の症例を経験した。症例は 70 歳男性, 肺炎で他院入院 中に突然吃音を発症. 当科初診時, 口腔・咽喉頭に器質的異常なく, 構音障害や失語症も認め なかった，語頭音のくり返しを主症状とする吃音を認め, 随伴症状を認めた，訓練は, 発話速 度低下訓練とカウンセリングを併用した。訓練実施後から吃音症状は徐々に軽減し, 訓練開始 3 カ月半でほほ消失した。本例の特徵は, 吃音が獲得性で突然発症している, 発話は語頭音の くり返しが多い，随伴症状がある，数カ月の訓練で著明に改善している，画像所見で突発した 吃音を説明できる病変がない, 発症誘因と推察される入院に伴う強いストレスがある, 吃音の 原因となる他疾患の可能性がないことがある。これらの特徵から, 本例は心因性吃音であると 考えられた。
\end{abstract}

索引用語：心因性吃音, 獲得性, 鑑別診断, 言語治療, 突発

\section{Sudden Onset Psychogenic Stuttering in an Elderly Patient —A Case Report——}

\author{
Shinichi Taniai $^{1)}$, Naoshi Maeara ${ }^{2)}$, Nobuaki Tanaka ${ }^{1)}$, Takaomi Kuriokal, \\ Masayuki Tomifuji ${ }^{1)}$, Koji Araki ${ }^{1)}$ and Akihiro Shiotani ${ }^{1)}$
}

\begin{abstract}
A 70-year-old male presented with unexpected psychogenic stuttering. He suddenly began to stutter while he was hospitalized with pneumonia. At the initial consultation to our department, the primary symptoms were severe part-word repetitions. However, laryngopharyngeal abnormalities, dysarthria, aphasia and neurologic abnormality were not observed in clinical observations. Additionally, we identified psychological episodes as being responsible for the onset of stuttering. Therefore, as a treatment for stuttering, we employed speech rate control training combined with counseling once every few weeks. As the training proceeded, stuttering frequency gradually decreased and ultimately disappeared three-and-a-half months after the start of treatment. Based on the absence of lesions that could explain the sudden onset of stuttering during brain imaging evaluations, the presence of a psychological episode, and no possibility of other disease, we diagnosed sudden onset psychogenic stuttering.
\end{abstract}

防衛医科大学校耳鼻咽喉科学講座 ${ }^{1)}:$ T 359-8513 埼玉県所沢市並木 3-2

国際医療福祉大学言語聴覚学科 ${ }^{2} ：$ \% 324-8501 栃木県大田原市北金丸 2600-1

${ }^{1}$ Department of Otolaryngology - Head and Neck Surgery, National Defense Medical College: 3-2 Namiki, Tokorozawa, Saitama 359-8513, Japan

${ }^{22}$ Department of Speech and Hearing Sciences, International University of Health and Welfare: 2600-1 Kitakanemaru, Ohtawara, Tochigi 324-8501, Japan

2014 年 7 月 23 日受稿 2014 年 10 月 29 日受理 
Key words: psychogenic stuttering, acquired, differential diagnosis, speech therapy, sudden onset

\section{はじめに}

獲得性吃音は発達性吃音とは異なり明らかな原因が あるとされ，大きく神経原性吃音（neurogenic stuttering) と心因性吃音（psychogenic stuttering） に分類されている，神経原性吃音は，頭部外傷，脳血 管疾患，神経筋疾患などが報告されており ${ }^{1)}$ ，わが国 でも中枢神経損傷による高次脳機能障害との併発例が 紹介されている2)。一方，獲得性としては少数である が, 情動的な要因が関係してまたは心理的な原因で発 症するとされるものに心因性吃音がある。海外では 1980 年代頃より報告されており ${ }^{1,3-5)}$ ，その特徵や原因 に関して，さまざまな議論が展開されてきた。その初 期の焦点は神経原性吃音との区別であり，鑑別条件は 器質的問題の有無である。 そして近年, 決定的な器質 的異常所見を見出せない場合は，単に除外診断とする のではなく，神経原性吃音との違いを明確にする必要 性が指摘されている。それは，神経原性の可能性がな くなったとき，発話症状や身体症状といった臨床所見 における明確な違いを見出すことによって心因性吃音 の確定診断を得ることであり，その診断に基づいて適 切なアプローチを行うべきという考え方である．先行 報告によると，心因性吃音は突然発症し ${ }^{1)}$, 発話は語 頭音のくり返しが最も多い1,4-6)。 また，極度な心理的 なストレスや不安が吃音の発症に関連しているとする 報告もある ${ }^{1)}$ ，しかし，心因性 (psychogenic) の範囲 は広いため, 現在までに除外診断の対象となりうるす べての要因が明らかになっているわけではない。すな わち, 心因性吃音の臨床像, 症状の特徵, 治療経過に ついては，神経原性との相違点を含め，いまだ不明な 点が多いといえる。そそのような状況のなかで，本症例 の病態を客観的に検証し臨床的対応を検討することは きわめて重要である.

今回, 高齢期になって突然吃音を発症した本症例に ついて，生理学的な検証を踏まえたうえで非流暢性症 状やその頻度, または吃音に特徵的な症状の分析・検 討を通して鑑別診断を行った。そして，言語聴覚士の 臨床にとって有益となる治療方法掞よびその妥当性に ついて検討した。

\section{症例}

症例は, 70 歳男性, 右利き. 仕事は退職しているが,
自宅で自立した生活を営んでいた。

主訴：吃音をなんとかしたい。

吃音の家族歴：なし。吃音歴：なし.

既往歴：右膝半月板損傷, 高血圧.

職業 : 元大工.

現病歴：X月 Y日肺炎で他医に入院, 抗菌薬の投与, 酸素吸入で肺炎は軽快した。廃用症候群に対しリハビ リテーション（リハ）を受けていたＹ＋10日の午後, リ八を待っている間，知人と話そうとしたところ，突 然ことばのくり返しを主とする吃音を発症。それまで に経験したことがない自身の話し方の異常に驚いたこ とを伝え，一定時間経過し症状が一過性のものではな いことを自覚すると不安が顕著となった，その後，症 状は持続，中枢神経疾患等を疑わせる所見がなかった ため原因不明のまま経過観察となった。吃音症状に変 化がない状態で入院生活を送り，そのまま自宅退院と なった，日常生活において症状が改善することがな かったため, 吃音の原因精査目的にて, 発症 30 日後 当院神経内科を紹介受診、神経学的所見，画像所見等 より神経疾患等は否定され，発症 93 日後に原因不明 の吃音として当科紹介.

頭頸部診察所見：咽喉頭には器質的な異常なく, 喉 頭運動は正常. 脳神経学的所見にも異常なく, 構音障 害はなかった。最長発声持続時間（MPT）は 13 秒, GRBAS 尺度は G1R1B0A0S0 であった。

頭部 MRI 所見：拡散強調画像では病変を認めず, FLAIR 画像で両側に陳旧性の虚血性変化を認めた(図 $1)$.

音声言語評価：初回評価では, 医師診察時の会話で のやり取り, 言語聴覚士との会話および鑑別に必要な 検査を行った，会話時に，顕著な語頭音のくり返しを 認めた。ささらにブロックとくり返しが混在したような ときには，太腿部を手でタップする随伴症状が見られ た。これは，手の動きが会話でくり返しのときのみに 出現し, それ以外のときは認められなかったためブ ロック症状と判定した。 また，他人との会話の機会を 避けることがあったことから，自己の吃音について否 定的に自覚していることは明確であった。しかし，発 話の工夫は認められなかった。基礎疾患として最も疑 われた認知機能について，長谷川式簡易知能評価又 ケール（HDS-R）を実施したところ 27 点であり，会 話での話し方・言語コミュニケーションの様子から失 




FLAIR 画像

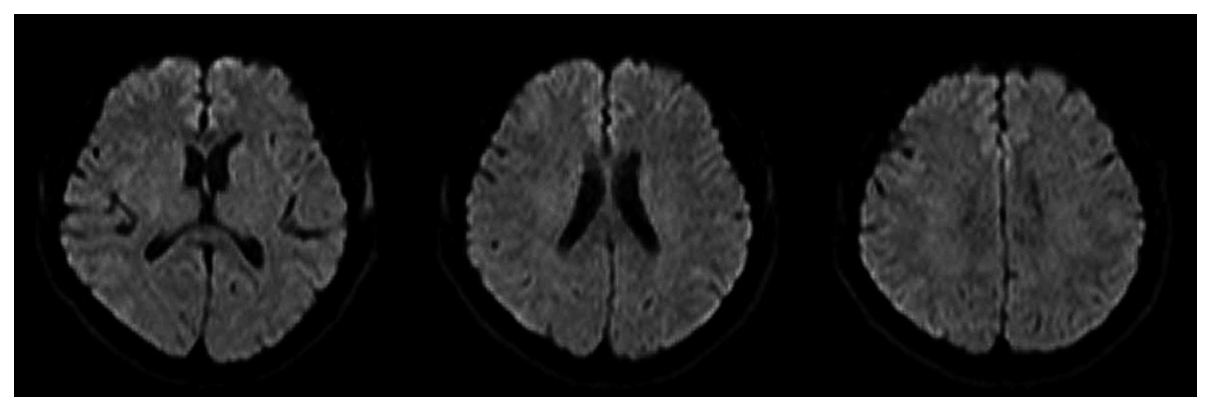

拡散強調画像

図 1 頭部 MRI：FLAIR およびDWI所見

語や高次脳機能緒障害を疑う所見は認められなかっ た。

\section{言語訓練と経過}

何の兆候もない状態で突然に語頭音のくり返しが顕 著に発症したことは，周囲からわざとどもっていると 言われたことなどから，本人にとって心理的ダメージ がきわめて大きかったことがわかる。そのため，まず は流暢な話し方ができなくなったわけではないことを 体験させることが必要と判断した。主要な訓練内容は (1)流暢性形成と(2)カウンセリングの併用である。カウ ンセリングは, STが共感的態度を示しながら, 発言 に制限をかけない雲囲気でネガティブな発言を誘導し ないこと, 自発的な発言内容を会話トピックとして広 げること，本人の悩みを一緒に考えていく態度を示す ことを目的に実施した。訓練は当科紹介当日の 103 病 日より開始した。訓練全体の経過を図 2 に示す。訓練 は当初週 1 回の頻度で実施し, 徐々に頻度を下げて 行った。 なお，訓練効果については，非流暢性症状の 質的分析と時間経過に伴う頻度の变化で測ることとし た。

流暢性を取り戻す感覚を提供するために, タッピン グ法を用いた発話速度低下訓練を導入した。これは, 1 モーラごとに自分の太腿部を手でタッピングすると いう方法である。タッピング法導入にあたっては，フ
レージング法・モーラ指折り法を試行し, 最も効果的 であったタッピングを用いることとした，実施にあ たっては，随伴症状を強化することにならないように 留意して施行した。 タッピング法は, 単語から開始し, 段階的に 2 文節文〜 5 文節文にレベルアップしていく 手順をとった。これにより，タッピング中は吃音症状 が減少し流暢性が向上する様子が観察された。発話速 度については, タッピングなしで 2.6 モーラ/秒, タッ ピングありで 1.8 モラ/秒となり，明らかに低下し ており，流暢性向上に影響したことがわかる。

一方で, 吃音症状が突発的に出現した要因を探るこ とも行った。まず器質的な問題がないことから，心因 性吃音の可能性を疑った。 そこで, 心因性吃音のトリ ガーとなりうるストレスの原因を探るべく，訓練中の 会話からその詳細を分析した。 その結果, 肺炎による 入院生活中のストレスや過去に妻が入院していた他の 病院内での制約の多い環境など，病院生活は自分が 思っていた以上に不自由を強いられる環境であったこ とを中心とした不満をきわめて顕著に訴え続けた。た とえば，お手洗いや気分転換に数分ほどベッドを離れ たときに,ものすごく厳しく注意・指導を受けるといっ たようなことを激高するように訴えた。 当初はその話 題を変えることで気分を落ち着かせてストレスを緩和 させることを試みた。しかし，それでも最後には話す 内容が入院中の不満に戻ってしまうことが常であり, 




図 2 訓練経過

^: 言語訓練実施日， $\triangle$ : 会話音声の評価日

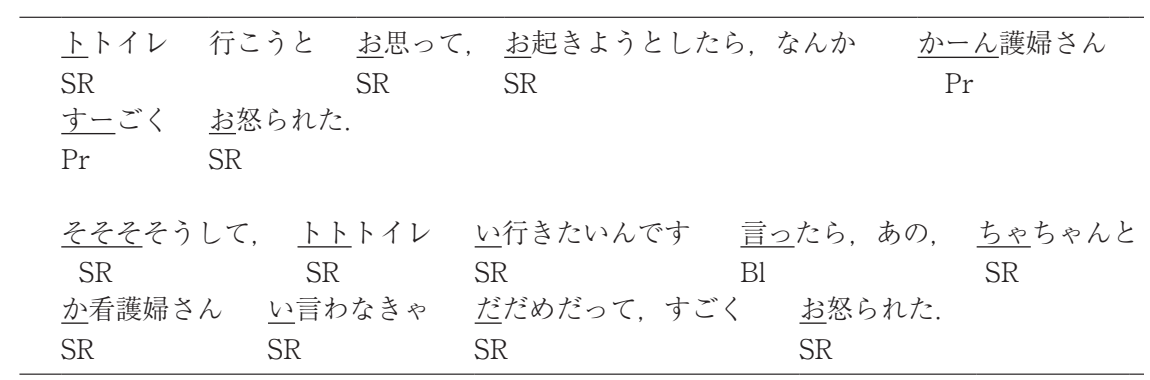

図 3 発話のサンプルの抽出例

$\mathrm{SR}$ : くり返し, $\mathrm{Pr}$ : 引き伸ばし, $\mathrm{Bl}$ : ブロック

本人が感じているストレスがきわめて特異的なもので あった。そこで，入院中のストレスが吃音発症の一因 となったと推察し, 訓練のなかで, 本人の抱えている 不満をみずからのことばで表出させることを重視した カウンセリングを行い，言語聴覚士は傾聴的態度で接 することを基本とした。このアプローチ中により，本 人は普段から感じていた不満をほぼ表出した。最初に 導入として会話を 5-10分, カウンセリングを20-25分, 発話速度低下訓練を 10-15 分の構成で行った。

\section{発話行動の分析}

\section{1. 方法}

まず, 非流暢性症状を抽出し,そのタイプ分類を行っ た。分析は，録音した訓練中の会話場面から，会話開 始約 1 分後から 100 文節までを筆者が取り出し，2名 のST が独立して非流暢性数をカウントし平均值を算 出した，図 3 は抽出方法の例である。取り出して書き 出した発話サンプルに判定を書き込んでいく作業を 行った，評価者の判定一致率は 89.4\%であった。また，
表 1 症状別の吃音出現回数

\begin{tabular}{|c|c|c|c|c|c|c|c|}
\hline 発症後 & $\mathrm{SR}$ & $\mathrm{Bl}$ & $\operatorname{Pr}$ & PWR & WR & $\mathrm{Ij}$ & 計 \\
\hline 109 日 & 40.0 & 1.0 & 3.5 & 1.5 & 0.5 & 5.5 & 52.0 \\
\hline 129 日 & 9.0 & 1.0 & 0.0 & 1.5 & 2.5 & 0.5 & 14.5 \\
\hline 173 日 & 12.0 & 0.5 & 0.0 & 0.5 & 0.5 & 0.0 & 13.5 \\
\hline 236 日 & 5.5 & 0.5 & 0.0 & 0.0 & 0.0 & 0.5 & 6.5 \\
\hline 285 日 & 4.5 & 0.0 & 0.0 & 0.5 & 0.0 & 1.5 & 6.5 \\
\hline 320 日 & 1.0 & 1.0 & 0.0 & 0.0 & 0.0 & 5.0 & 7.0 \\
\hline
\end{tabular}

症状の生起位置を語頭, 語中, 語尾に分けて集計した. 会話場面の評価は，発症後109日，129 日，173 日， 236 日，285日，320日の計 5 回とした。

\section{2. 結果}

表 1 に非流暢性が出現した文節数を示す。非流暢性 を分析したところ，「“語頭音節”のくり返し（SR）」, 「“語句” のくり返し (WR)」「“語の部分的な”くり


入 $(\mathrm{Ij}) 」$ の 6 タイプに分類することができた. 
そのうえで頻度を見てみると,初回（発症 109 日後） の非流暢性頻度が52文節もあり，そのほとんどが「SR」 （40.0 文節）であり 2 番目に「 $\mathrm{Ij} 」(5.5$ 文節) であった。 次いで Pr 3.5 文節, 「PWR 1.5 文節, 「Bl」 1 文節, 「WR」 0.5 文節であった。 その後, 1 週間間隔の訓練過程を 経て 20 日後の 2 回目のセッション時（発症 129 日後) の頻度は 14.5 文節と, 症状が大幅に軽減している. 内訳は $\lceil\mathrm{SR} 」 9$ 文節, 「Ij」0.5 文節, 「Pr」0 文節, 「PWR」 1.5 文節, 「Bl」 1 文節, 「WR」 2.5 文節であった。さ らに訓練を継続し，発症 173 日では，6.5 文節にまで 減少した。これは吃音を有しない人でも起こりうる非 流暢性の範囲である。

また, 症状が生起した位置を調べたところ，5回の 計測すべてにおいて語頭での出現が 100\%であり，語 中や語尾での非流暢性の出現は認められなかった。さ らに訓練を進めると主要な非流暢性症状に変化が見ら れるようになった。つまり，顕著に出現した「SR」 は発症後109〜236 日までの間，非流暢症状のほぼ主 要な部分を占めていたが, 285 日 (4.5 文節) 〜 320日（1 文節）までの 1 力月の期間でほほ消失した。しかし， それに代わり発症後 129 日から 285 日の間ほとんど出 現していなかった「Ij」（5 文節）が目立つようになっ てきた.「Ij」は109日後の非流暢性のなかで「SR」 に次いで多かったタイプであり，8 月後に109日後 と同程度の出現数を示したことになる.

整理すると, 非流暢性症状の主症状は「SR」であっ た。そして、初期に高頻度たっった いう短期間で大幅に改善し, その後 6 カ月で徐々に減 少していった.また, その一方でほぼ出現していなかっ た「Ij」が 7 カ月後に再び増加するという経過が示さ れた。

\section{考察}

\section{1. 鑑別診断}

神経原性吃音の原因には, 頭部外傷, 脳血管疾患, 認知症, パーキンソン病, 薬物の影響などが報告され ている1)。その特徵として Helm-Estabrooks ${ }^{4)}$ は, (1) 非流暢性は，文だけでなく単語でも起こる，(2)不安は 生じない, (3)くり返し・引き伸ばし・ブロックは語頭 音に限定されない, (4)随伴症状はほとんど出現しない, (5)適応効果は見られない，6吃音は発話課題に関係な い, としている。一方, 心因性吃音は後天性に発症す る吃音としては少数であり, 神経系疾患によらず感情 的や心理的な原因で発症するとされている。，その発話 特徵としては，語頭音のくり返しが主である ${ }^{1,4-6)}$ とす
る報告が最も多く，他に引き伸ばし・ブロックもある という報告がある7,8)。発症は突然で8)，適応性効果は 認められない ${ }^{3,8}$. ささらに, 吃音の特徵が発達性吃音 に類似すること ${ }^{3,8,9)}$ ，吃音が特定の場面で見られるこ $と^{8)}$, 随伴症状が確認された報告1,7) がある一方, 出現 する場合としない場合が混在しているという報告もあ $る^{7-9)}$.

本例の突発した吃音の原因については, 70 歳とい う高齢であり, 唯一確認された器質的異常所見として はMRIにて陳旧性の脳虚血性変化が示されたことで ある、そのため，脳血管障害による神経原性吃音と心 因性吃音との鑑別が必要となる。脳血管障害により吃 音が発症することは, 以前より知られているが2,10,11), その責任病巣についてはいまだ議論の段階であろう. 言い換えれば，吃音や非流暢性の発現が関与寸る脳の 特定領域は確定されていない. したがって, 本症例に 認められるような陳旧性の脳虚血性変化が吃音または 発話の非流暢性を引き起こしている可能性は今のとこ ろ低いと考える。ただ，この点は今後の課題として検 証が必要であろう。 $\mathrm{Ward}^{1)}$ が指摘するように，両者 の鑑別は非常に難しい問題であり慎重な検討が必要で ある。

本例に当初見られた大腿部を手でタップする運動に ついては，手の動きが会話でくり返しのときのみに出 現し, それ以外のときは認められないこと, 神経内科 で神経筋疾患等が否定されたこと, その後症状の軽減 に伴い手の動きが消失していることから，吃音の随伴 症状であったと考えられた。

本例の吃音症状の特徵としては, (1)突然発症してい ること, (2)神経筋疾患等の吃音の原因となる疾患の可 能性がないこと, (3)画像所見で突発した吃音を説明で きる病変がないこと, (4)発話は語頭音のくり返しが多 いこと，(5)随伴症状が見られること，といった状態に 加え, 訓練過程に伴う症状の変化としては, (6)数カ月 の訓練で著明に改善していることが挙げられる，そし て要点は, (7)発症誘因と推察される心理的なエピソー ド（以下，心理的トリガー）である。発話症状の語頭 音のくり返しが顕著に出現していること, 随伴症状が 認められることといった特徵は、これまで報告された 心因性吃音の報告例との合致が多く見られる.さらに， 発症の誘因については，交通事故による身体的損傷が ストレスの引き金になった症例5,9), 今後の生活に対 する不安 ${ }^{2}$ などの報告がある。一方，明らかな原因を 特定できなかったとの報告もある11. このように，多 くの報告では何らかのエピソードによって吃音が発症 
したとされている。本例の場合，吃音発症は，入院中 の病院に対する不満を強く漏らすことがあったことな どから，入院によるストレスが考えられる。つまり， 肺炎発症による入院によって生じたストレス, 環境変 化に伴う不安や不満, 今後に対しての生活に対しての 不安などが心理的トリガー（ネガティブトリガー）と なり，突然吃音を発症させた可能性が考えられる，本 例は吃音発症時に麻疩や失調等の神経学的所見を認め なかったこと，MRIの病変が陳旧性であったことを 考えると,この病変が突発した吃音を発症させたとは 考えにくい，このように本例の所見を，先行研究を踏 まえて総合的に判断すると, 発話の特徵, 発症の経過, 心理的トリガーと思われるエピソードがあることか ら，心因性吃音であると考えるのが妥当であると考え る.

\section{2. 言語治療の効果}

心因性吃音の治療については, 言語治療により短期 間で回復している例が多いこと年, 、リドカイン注射 が有効であった例 ${ }^{5}$ ， Delayed Auditory Feedback （DAF）が有効であったとする報告3)，心理療法で改 善した例9), 心理療法と言語治療の併用で改善した例7) などの報告がある.

本例の吃音は, 入院に伴う種々のストレスがネガ ティブトリガーとなり, 発症したものと思われる。そ れに対して, 訓練中に行ったタッピングはリズム効果 としての要因が動いたことで, 流暢性が短期間で向上 した。この流暢性体験が流暢性トリガー（ポジティブ トリガー）として働いた可能性がある。同時に言語聴 覚士の傾聴的な態度によって設定された自由な発言環 境は, 流暢性を促進する土䁃となり, この両者の相互 作用によって顕著に症状が改善されたと考えることが できる (図 4)。これは, Helm-Estabrooks ${ }^{4)}$ が 30 歳
男性の心因性吃音に対し, 発話速度調整訓練を施行し て効果があったとする報告に類似している.

音声障害の分野では, 声帯の運動に異常がないにも かかわらず，意図的な発声ができず失声状態となる心 因性失声症と呼ばれる病態がある。心因性失声症への 音声訓練の手技として，咳払いや母音のハミングから 有響音を誘導する方法が知られている ${ }^{12,13)}$. これは, 発声や喉を使うことを意識せずに有声音を誘導したる ことにより ${ }^{14)}$ ，結果的に「有声音の産生に“気づく”」 といったことを基本と考える手技である。本例に用い た発話速度低下訓練は，この訓練と同様の効果があっ たものと推察することができる。つまりタッピングす ることで自然なリズム同期で発語タイミングを図るこ とができる，その結果，意識せずに流暢性を体験する ことができ，患者自身が「吃音症状が少ない発話が可 能になることに“気づく”」ことができたため安心に つながったと考えられる。タッピングが，心因性失声 症に扮ける咳払いや八ミングと同様な効果をもたら し, 吃音症状の少ない発話がみずからの発話に対する 自信となったのであろう。加えて，ストレスとなった 執拗な不満は, 吐き出させることでくり返し症状とと もに急激に減少している。本症例の場合，性格または 心理的特性として自身で納得し折り合いがつくという ことが重要な要因になった可能性がある。発症した吃 音症状に対して，不満を吐き出しそれを受容してくれ たという納得とタッピングによる流暢性体験に対する 自信という納得が相乗効果をもたらした可能性が考え られる。

本邦においては，心因性吃音の報告は，失語症と合 併した 1 例の報告があるのみである2).さらに本報告 のように言語評価を継時的に詳細に検討した報告はな い. その観点においても，本例の経過は心因性吃音の

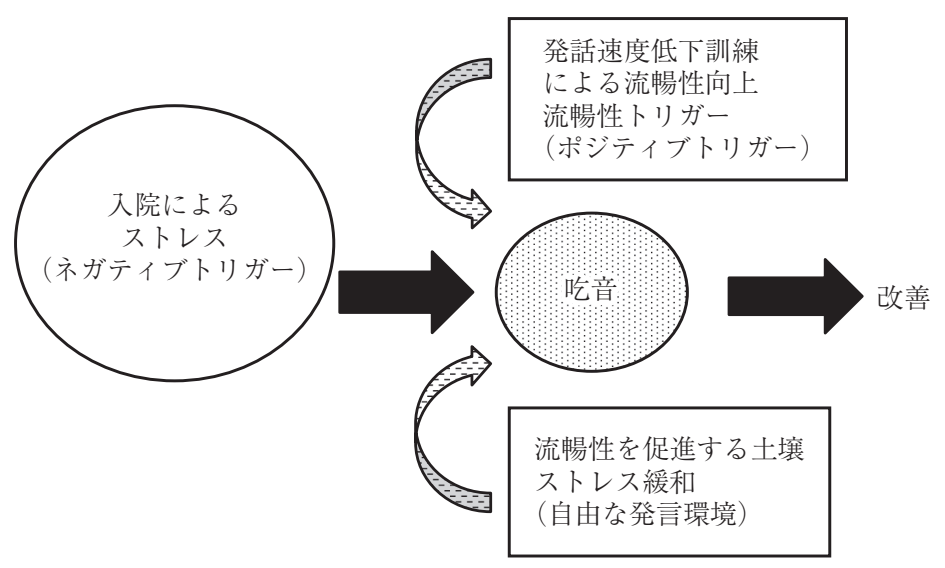

図 4 本例の回復メカニズム 
特徴と臨床経過を示すことのできた貴重な症例であっ たといえる。

本論文の要旨は第 58 回日本音声言語医学会総会・学術講演 会 $(2013$ 年 10 月, 高知県) にて発表した.

謝辞 本例の評価·訓練にあたり貴重なご助言を頂きました， 日高病院の谷 哲夫先生に深謝いたします。

利益相反自己申告：申告すべきものなし．

\section{文献}

1) Ward D: Sudden onset stuttering in an adult: Neurogenic and psychogenic perspectives. J Neurolinguistics, 23: 511-517, 2010.

2）谷 哲夫, 清水倫子, 赤根 良, 他: 左前頭葉内側面損傷 後超皮質性運動失語を呈した 1 例に打ける acquired stuttering の分析. 失語症研究, $20 ： 327-336,2000$.

3) Deal JL: Sudden onset of stuttering: case report. J Speech Hear Disord, 47: 301-304, 1982.

4) Helm-Estabrooks $\mathrm{N}$ and Hotz G: Sudden onset of "stuttering" in an adult: neurogenic or psychogenic? Semin Speech Lang, 19: 23-29, 1998.

5) Dworkin JP, Culatta RA, Abkarian GG, et al: Laryngeal anesthetization for the treatment of acquired disfluency: a case study. J Fluency Disord, 27: 215-226, 2002.

6) Chang SE, Synnestvedt A, Ostuni J, et al: Similarities in speech and white matter characteristics in idiopathic developmental stuttering and adult-onset stuttering. J Neurolinguistics, 23: 455-469, 2010.

7) Roth $\mathrm{CR}$, Aronson $\mathrm{AE}$ and Davis LJ Jr: Clinical studies in psychogenic stuttering of adult onset. J Speech Hear Disord, 54: 634-646, 1989.

8) Baumgartner J and Duffy JR: Psychogenic stuttering in adults with and without neurologic disease. J Med Speech Lang Pathol, 5: 75-95, 1997.

9) Mahr G and Leith W: Psychogenic stuttering of adult onset. J Speech Hear Res, 35: 283-286, 1992.

10）佐藤睦子, 細野聡美, 大平聡美, 他：脳梗塞により後天性 吃 acquired stuttering を呈した 1 例。臨床神経心理，15： 31-36, 2004.

11）谷 哲夫，見上昌睦：脳損傷後吃様症状を呈した 3 例の発 話特徴。音声言語医学, $40 ： 133-140,1999$.

12）廣瀬 肇：音声障害の臨床，インテルナ出版，東京，99100 頁, 1998.

13）城本 修: 心因性発声障害の音声治療一音声治療の実際. ST のための音声障害診療マニュアル（廣瀬 肇監修）、イ ンテルナ出版, 東京, 152-154 頁, 2008.

14）小林範子：第 1 章音声障害 指導・訓練。標準言語聴覚障 害学 発声発語障害学 (熊倉勇美, 他編), 医学書院, 東京, 82-83 頁, 2010 .

別刷請求先： $=359-8513$ 埼玉県所沢市並木 3-2 防衛医科大学校耳鼻咽喉科学講座 谷合信一 